\title{
Follicular Lymphoma International Prognostic Index 2
}

National Cancer Institute

\section{Source}

National Cancer Institute. Follicular Lymphoma International Prognostic Index 2. NCI

Thesaurus. Code C137658.

A prognostic index designed to be used for patients with follicular lymphoma to stratify them by risk. The index uses 5 parameters: age (less than 60 years or greater than or equal to 60 years), serum beta 2 microg lobulin (normal or elevated), hemoglobin level (less than $12 \mathrm{~g} / \mathrm{dL}$ or greater than or equal to $12 \mathrm{~g} / \mathrm{dL}$ ), bone marrow involvement (present or absent), longest diameter of largest involved node (less than $6 \mathrm{~cm}$ or greater than or equal to $6 \mathrm{~cm}$ ) and divides patients into 3 risk groups: low (0 risk factors), intermediate (1-2 risk factors), high (3-5 risk factors). 